\title{
Government initiatives for upgradation of the Indian textile industry
}

See end of the paper for authors' affiliations BABITA BHANDARI Department of Clothing and Textiles, College of Home Science, G.B. Pant University of Agriculture and

Technology, PANTNAGAR (UTTARAKHAND) INDIA

Email : babita.bhandari55555

@gmail.com
ABSTRACT : Indian textile industry is a major contributor to the Indian economy which is evident by its high employment generation capability and export potential. The industry comprises of various segments ranging from capital intensive spinning to labour intensive garmenting and highly unorganized sectors like handloom, sericulture, etc. For effective and efficient implementation, the industry requires upto date technology, skilled workforce, and funds for procuring infrastructure, machinery, etc. Recognizing the significance of the industry, Government of India has launched various schemes under the aegis of Ministries of Textiles and Commerce. These schemes have helped not only in augmenting the domestic market but also realizing its true potential in export. Each scheme has specific objectives covering different segments of the industry. Guidelines are issued for the implementation, monitoring and evaluation of the projects for which various committees are also formed. An attempt has been made through the article to present brief description about different schemes launched for betterment of the textile industry.

KEY WORDS: Development, Government, Indian textile industry, Schemes, Upgradation

- HOW TO CITE THIS PAPER : Bhandari, Babita and Rani, Anita (2017). Government initiatives for upgradation of the Indian textile industry. Asian J. Home Sci., 12 (1) : 283-288, DOI: 10.15740/HAS/ AJHS/12.1/283-288. 